
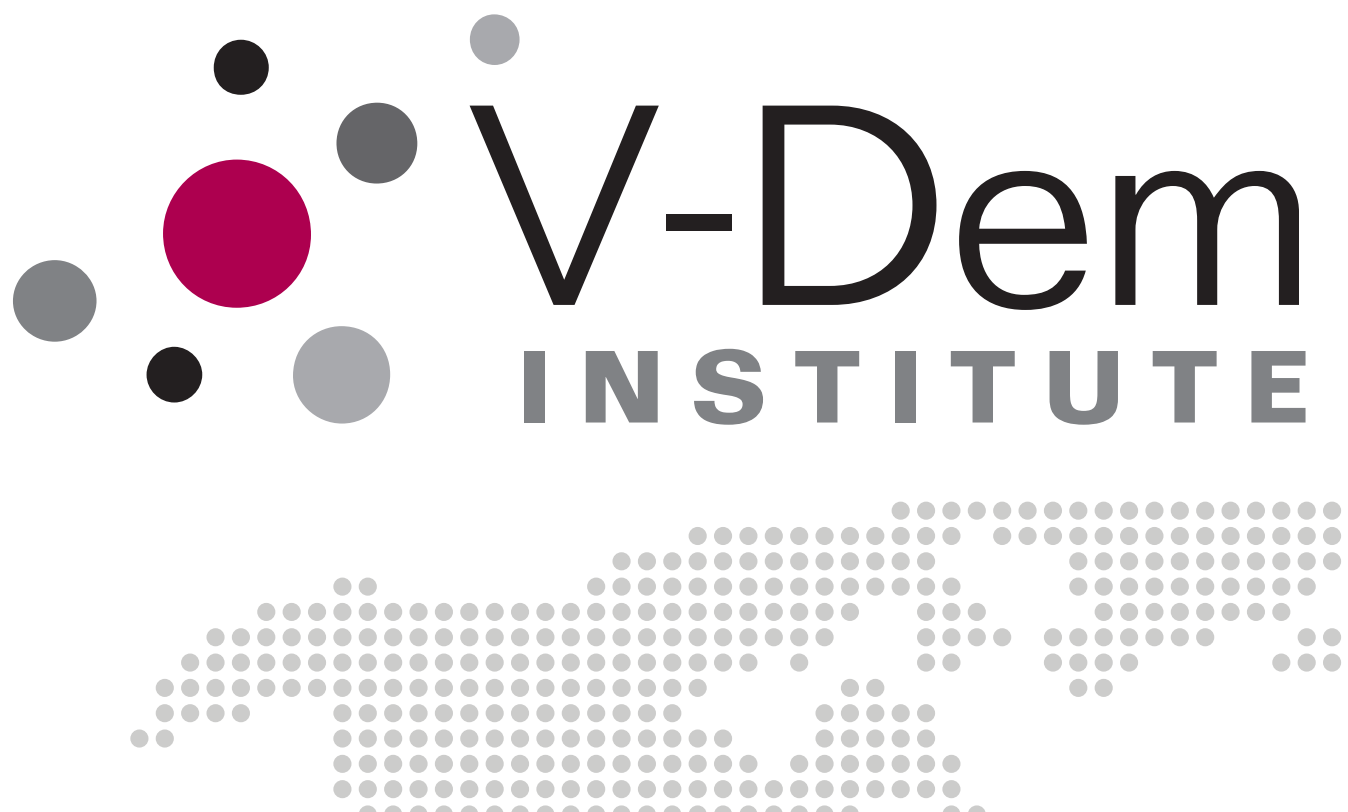

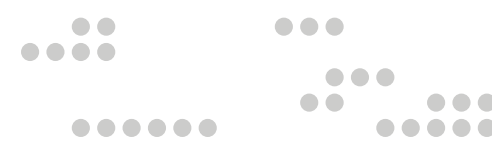

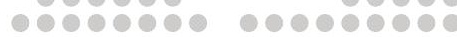

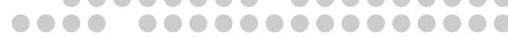

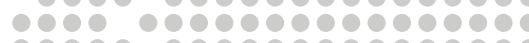

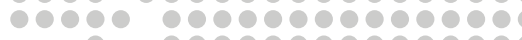
00

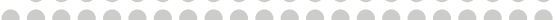

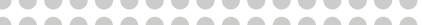

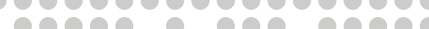
rerob

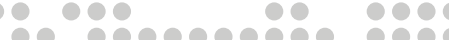

Democracy, Quality of Government, and Public Goods Provision: The Case of Water Management Marina Povitkina Ketevan Bolkvadze

00000000

0090900

000000

00000

10000

000

000

10

10

O

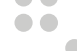

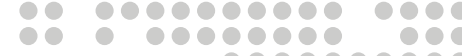

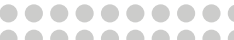

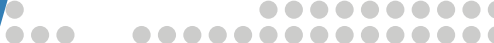

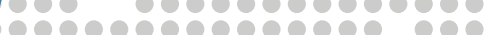

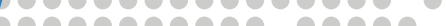

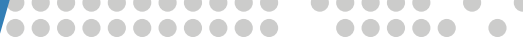

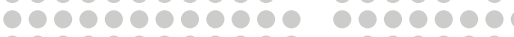
1000000000000 000000 60000000000000 00000 10000000000000 1000000000000000

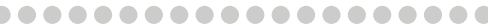

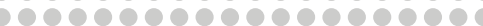

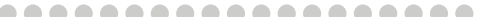

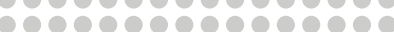



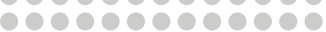

0000000000

0000000000

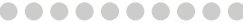

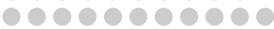

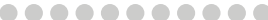

-

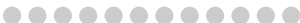
robróró

-

080000000

0000000

100000

000000

000

100

10

10 
Varieties of Democracy ( $\mathbf{V}$-Dem) is a new approach to conceptualization and measurement of democracy. It is co-hosted by the University of Gothenburg and University of Notre Dame. With a V-Dem Institute at University of Gothenburg with almost ten staff, and a project team across the world with four Principal Investigators, fifteen Project Managers (PMs), 30+ Regional Managers, 170 Country Coordinators, Research Assistants, and 2,500 Country Experts, the V-Dem project is one of the largest ever social science research-oriented data collection programs.

Please address comments and/or queries for information to:

V-Dem Institute

Department of Political Science

University of Gothenburg

Sprängkullsgatan 19, PO Box 711

SE 40530 Gothenburg

Sweden

E-mail: contact@v-dem.net

V-Dem Working Papers are available in electronic format at www.v-dem.net.

Copyright $@ 2018$ by authors. All rights reserved. 


\title{
Democracy, Quality of Government, and Public Goods Provision: The Case of Water Management*
}

\author{
Marina Povitkina ${ }^{\dagger}$, Ketevan Bolkvadze
}

* V-Dem data collection was supported by Riksbankens Jubileumsfond, Grant M13-0559:1, PI: Staffan I. Lindberg, V-Dem Institute, University of Gothenburg, Sweden; by Knut and Alice Wallenberg Foundation to Wallenberg Academy Fellow Staffan I. Lindberg, Grant 2013.0166, V-Dem Institute, University of Gothenburg, Sweden; as well as by internal grants from the Vice-Chancellor's office, the Dean of the College of Social Sciences, and the Department of Political Science at University of Gothenburg. V-Dem performed simulations and other computational tasks using resources provided by the Notre Dame Center for Research Computing (CRC) through the High Performance Computing section and the Swedish National Infrastructure for Computing (SNIC) at the National Supercomputer Centre in Sweden, SNIC 2016/1-382 and 2017/1-68. V-Dem Institute specifically acknowledges the assistance of In-Saeng Suh at CRC and Johan Raber at SNIC in facilitating the use of their respective systems.

$\dagger$ University of Gothenburg, marina.povitkina@gu.se

‡ University of Gothenburg, ketevan.bolkvadze@gu.se 


\section{Abstract}

A large strand of research has argued that democracy with its broad representation and electoral accountability is beneficial for the provision of public goods to the general population. However, there is a large variation in how the existing democratic regimes perform, implying that democratic institutions are not sufficient to secure people's wellbeing. The aim of this paper is to explore the sources of this variation. With the point of departure in theories on democracy, quality of government, and public goods provision, we posit that the way democracies perform in the delivery of public goods to their citizens depends on the presence of good quality institutions that shape the implementation of public policies. Using a mixed method design, this paper both empirically tests this proposition and offers an in-depth investigation into the mechanisms behind the interdependent relationship. In the first stage of our analysis, we explicitly test the conditional effects of democracy and quality of government on public goods provision using water quality as an example of such public good. The results show that democracy is associated with higher water quality only in countries where quality of government is high. In contexts with low governmental quality, more democracy even seems to be associated with higher water pollution. In the second stage of our analysis, we proceed with examining the mechanisms of how poor quality of government disrupts the positive effects of democracy on people's access to safe drinking water using interview data from a typical case of Moldova. 


\section{Introduction}

The third wave of democratization has brought up much interest in the performance of democratic governments. The existing literature is filled with empirical studies exploring the effects of democracy on different indicators of human wellbeing (e.g., Helliwell, 1994; Przeworski, 2000; Gerring et al., 2005; Ross, 2006; McGuire, 2010). However, there is a large variation in the performance of the existing democracies that is largely underresearched. The aim of this paper is to explore the sources of this variation.

Political regimes with developed democratic institutions are believed to provide more welfare to their citizens than less free political systems. Regular free and fair elections with universal suffrage, freedom of expression, freedom of association, and opportunities for deliberation are said to create favorable conditions for the wide public service delivery. Aiming to please the majority of the electorate and win their support in the next elections, democratic rules supposedly have an incentive to deliver widely demanded public goods ${ }^{1}$ as opposed to the autocrats who rather focus on satisfying wishes of the narrow elite to gain support necessary to stay in power (Bueno De Mesquita, 2003; Lake and Baum, 2001; McGuire and Olson, 1996; McGuire, 2010). As citizens can replace political leaders who do not deliver, democratic leaders are assumed to be more accountable to the general public than the autocrats (Acemoglu and Robinson, 2006; Sen, 1999). Freedom of expression can help raise the salience of political failures in public goods provision, which makes citizens more likely to hold politicians accountable, while freedom of association allows citizens to mobilize and lobby their interests for more public goods provision.

Despite there are theoretical reasons to believe that democratic institutions are favorable to the provision of essential public goods, the existing democracies today do not deliver social welfare uniformly well. The literature has offered a number of explanations why this can be the case. Democratic leaders are known to be short-sighted and therefore inclined to focus more on outcomes that bring visible benefits in the short-run, while the provision of many public goods requires long-term commitments (Haggard, 1991). Opportunities for clientelism or vote-buying can distract the attention of political leaders from the universal supply of public goods and let them focus on the provision of targeted goods or private benefits instead (Hicken, 2011; Kitschelt, 2000; Keefer, 2007). Additionally, democracies can simply lack the

\footnotetext{
${ }^{1}$ In economics, public goods are defined as goods that are non-excludable and non-rivalrous. However, in political science, it is common to refer to them as universal benefits that people receive from the government, such as healthcare, education, clean water supply, or electricity, although in practice, people can be excluded from these benefits (Min, 2015). As in this paper we aim to contribute to the political science literature on public goods provision, we refer to public goods consistently with their understanding in the political science, although we acknowledge that it is not uncontroversial.
} 
capacity to deliver the desired outcomes due to malfunctioning institutions (Rothstein, 2011). Empirical research on the relationship between the democratic forms of government and public goods provision have predominantly reported positive effects: more democratic states tend to deliver more public goods and services than non-democratic countries (e.g., Lake and Baum, 2001; Bueno De Mesquita, 2003; Deacon, 2009). Some scholars evidence that it is experience with democratic institutions that secures public goods provision rather than the current level of democracy (e.g., Keefer, 2007; McGuire, 2010; Gerring et al., 2012; Min, 2015). While the role of factors that disrupt the functioning of democracies are well-abound in the literature, very few empirical studies actually account for them in their statistical tests, thus failing to explain the variation in the performance of existing democratic regimes. The studies that do, however, do not seem to provide convincing evidence of the mechanisms behind the relationship patterns they find (Hanson, 2015; Knutsen, 2013; Boräng et al., 2016).

In this paper, we address both these research gaps by using nested research design suggested by Lieberman (2005). First, we argue that while democratic institutions shape access to the political power and preference aggregation in the decision-making, they do not necessarily guarantee that these decisions get implemented. In order to better understand the variation in the performance of democracies in public goods provision, we have to turn our attention to the political institutions that shape the exercise of the political power or rules that shape the implementation of public policies. We further posit that the performance of democracies is conditional on the presence of such well-functioning institutions and test our argument by modeling the interaction between democracy and governmental quality. In particular, we test the interdependent effects between these two sets of political institutions on the provision of water quality, measured with biochemical oxygen demand (BOD) and the level of wastewater treatment, as an example of a public good. Second, we proceed by investigating the mechanisms behind the interdependent relationship by choosing a typical case of Moldova, which scores high on most democracy indicators, however, exhibits persistently low levels of institutional quality. To illustrate the case, we use original triangulated interview data collected by the authors in spring 2016.

The rest of the paper proceeds as follows. First, we introduce the theoretical framework of the study and hypothesize how and why the quality of institutions that shape the implementation of public policies can moderate the effect of democracy on the provision of public goods. Second, we introduce the research design and present the analysis, starting with methods and findings in the Large-N part and then proceeding with the analysis of interview data from the typical case. We conclude by discussing our findings. 


\section{Theoretical background and previous research}

\subsection{Democracy and public goods provision}

Democratic institutions are believed to benefit people's welfare. First, "rule of the people" in itself implies that decision-making process reflects the interests of the majority. Both in democratic and authoritarian regimes, political leaders are accountable to the support group that keeps them in power, which provides the incentive for rulers to meet the demands of this support group or "winning coalition" (Bueno De Mesquita, 2003). As in democracies the winning coalition comprises of voters that elect political leaders, political leaders benefit from addressing the interests of the majority of voters rather than focusing on the interests of the few, as is the case in non-democratic regimes. It can simply be more costly for political leaders in democracies to buy support of the majority with private goods or vote-buying than commit to public service delivery and satisfy the demands of the majority (Lake and Baum, 2001; McGuire and Olson, 1996). This makes democratic rules more likely than the autocrats to extend social welfare universally and deliver public goods, such as education, healthcare, water or sanitation (McGuire, 2010).

Second, developed freedom of expression in democracies facilitates the flow of information and can help people recognize lack of public goods provision as a political failure. This increases the salience of political problems and allows citizens to hold politicians accountable for insufficient public service delivery by giving their votes to alternative candidates in the coming elections (Sen, 1999). Third, freedom of association also helps people mobilize into civil society organizations or protests, lobby their interests in politics, and demand public goods.

However, despite there are strong theoretical reasons to believe that democracy is associated with higher public service delivery, many democracies do not seem to do uniformly well in safeguarding the wellbeing of their citizens. There are a number of reasons brought up in the literature explaining why this can be the case. First, due to short electoral cycles, democratic leaders have an intrinsic motivation to prefer projects that take short time to implement and that produce visible outcomes quickly (Haggard, 1991; Keefer, 2007). It makes it easier for the population to judge their performance and increases the likelihood they will gain support in the next elections. Providing public goods, however, is often a long-term undertaking and requires continuous policy commitments that can withstand the change in governments. Second, due to short time horizons, politicians often engage in vote-buying and clientelism to secure support in the coming elections, attending to the 
interests of narrower groups rather than providing universal benefits (Hicken, 2011; Kitschelt, 2000). Third, some democracies are simply incapable of delivering outcomes desired by the citizens due to malfunctioning institutions and weak state capacity (Bäck and Hadenius, 2008; Sikkink, 1991; Rothstein, 1998, 2011; Miller, 2000; Rothstein and Teorell, 2008; Acemoglu and Robinson, 2012; Fukuyama, 2011, 2013).

Some empirical studies find that citizens of more democratic regimes tend to receive more social benefits than citizens of less democratic states (e.g., Lake and Baum, 2001; Bueno De Mesquita, 2003; Deacon, 2009). Others show that it is experience with democracy that matters for public goods provision rather than the current stage of democratic development (Keefer, 2007; McGuire, 2010; Gerring et al., 2012; Min, 2015). However, one of the major drawbacks of these studies is that they do not account for factors that might disrupt functioning of democracies in public goods provision and do not explain the variation in the existing democracies.

Democratic institutions shape access to political power and preferences aggregation in the decision-making and do not necessarily guarantee that these decisions get implemented. In order to fully understand the performance of democracies, we have to also turn our attention to how political power is exercised or institutions that shape the implementation of political decisions. As Huntington (1991, 9-10) notes:

Governments produced by elections may be: inefficient, corrupt, short-sighted, irresponsible, dominated by special interests, and incapable of adopting policies demanded by the public good. These make such governments undesirable but they do not make them undemocratic. (...) [Therefore,] democracy [should be] clearly distinguished from other characteristics of political systems.

\subsection{Quality of government and public goods provision}

Institutions that shape the implementation of policies include rules that guide the functioning of public administration and therefore determine states' bureaucratic capacity, the prevalence of rule of law that secures obedience to laws, and the extent of corruption, in both grand

and petty forms (Rothstein et al., 2012; Charron and Lapuente, 2010, 2011). These aspects are crucial determinants of government quality and they may affect the performance of democracies in public goods provision in a number of ways.

Favorable rules shaping the functioning of administrative apparatus stem from the Weberian model of a capable bureaucracy that implies meritocratic recruitment and predictable career 
with long-term rewards for the bureaucrats, such as job security and foreseeable salary. Employment by merit increases the likelihood that the chosen employees will be competent in their responsibilities. Provision of many public goods, such as clean water or air, often requires extensive expertise and well-developed action plans oriented to long-term implementation and quality maintenance. Competent professionals, using their knowledge and experience, are more likely to develop these action plans in effective manner. Predictable career and salary create motivation for individuals to stay within the government and thus increase competence over time. Attractive employment conditions also reduce incentives for bureaucrats to engage in corrupt practices for personal short-term gain (Evans and Rauch, 1999). Strong wellfunctioning bureaucracy can also constrain democratic leaders in their actions and secure policy implementation despite incentives for short-signed behavior in democracies (Cornell, 2014).

Strong rule of law, which implies obedience to the law both by the general public and lawmakers and equality of all actors under the law before the courts, can secure commitments to policy objectives and thus facilitate reaching long-term goals, such as many initiatives directed towards public goods provision. Weak rule of law also creates opportunities for public officials to misuse their office for private gain and engage in corruption, which is detrimental for public goods provision.

Wide embezzlement of public funds diminishes the extractive capacity of the state as public revenues are diverted from public goods provision to government officials' private use. It also reduces incentives for individuals to pay taxes, which could otherwise contribute to public goods budget. Petty bribery decreases the coercive capacity of the state and hampers policy implementation, as bureaucrats can have an incentive accept bribes instead of enforcing compliance (López and Mitra, 2000; Damania et al., 2003).

Quality of government may also impact policy choices of democratic leaders. There are few incentives for politicians to invest in public goods provision if they know that current institutions make public administration incapable of successful policy implementation (Dahlström et al., 2013). Additionally, grand corruption can pave the way for special interests to increase their influence over decision-making in democracies and divert policy preferences away from the public good. In a similar manner, if judges are not independent and can be bribed, it is easier for powerful interest groups to impose their preferences on the courts and override laws.

Some claim that for delivering certain public goods and services, some forms of corruption can be functional. For example, ethnic favoritism or clientelism can favor the delivery of targeted 
goods, such as schools, healthcare centers or water boreholes (Zarazaga, 2014; Walton, 2013; Huntington, 1968). In this paper, we focus on those welfare benefits that are difficult to exclude people from and that require universal provision. We believe that these types of goods pose a particular challenge for democracies, as they usually bring diffused benefits and take a long time to deliver. We posit that high quality of institutions that shape the implementation of public policies help democracies provide public goods, while low institutional quality is a key factor that keeps current democratic governments from successfully delivering welfare to their citizens. Our hypothesis to test is:

$H_{1}$ Performance of democracies in public goods provision is conditional on their quality of government ${ }^{2}$

\section{$3 \quad$ Research design and analysis}

\subsection{Water quality as a public good}

In our study, we test the proposed hypothesis on water quality as an example of a public good. In the economics literature, pure public goods are defined as goods that are non-excludable and non-rivalrous. As it is possible to clean up water resources selectively, providing safe water only to certain areas and not others, and, naturally, to limit access to water, it is problematic to classify water quality as a pure public good. Instead, it would rather be referred to as quasi-public good in economics. Nevertheless, political scientists often refer to access to safe drinking water as a public good that ideally should be provided universally and enjoyed by everyone, even if it not always is. In this article, we follow the tradition set by political science to achieve consistency and refer to water quality as a public good, although we acknowledge that this approach is not uncontroversial.

Provision of clean drinking water is a complex long-term undertaking. While building pipes and boreholes can ensure access to water within a relatively short time frame, reaching and maintaining good drinking water quality is a long-term project. It is connected to reducing water emissions, building and maintaining water treatment plants, as well as maintaining water's self-cleaning properties by sustaining the health of aquatic ecosystems and biodiversity. As access to clean drinking water is people's basic need and is essential for human wellbeing, the issue of water quality has seemingly high visibility. However, it takes a relatively long

\footnotetext{
${ }^{2}$ While based on the existing theories we have some expectations on how the relationship patterns in interaction can unfold, we do not formulate specific hypothesis, letting the patterns reveal themselves during the empirical analysis.
} 
time before the results from actions to purify water sources become visible to the general public. This slow response of water quality to policy actions and complexity of the issue provides a constant incentive for the democratic rulers to focus on other public policies, that yield short-term results, simply to make it easier for the public to evaluate government actions. $^{3}$

The water issues are complex. Water ecosystems are intimately dependent on the quality of forest surrounding the waterways and therefore are inherently connected to forest management. It requires strong expert knowledge and awareness of the complexity of water management problems. Water management, therefore, requires consultation with scientists, a coherence of goals between different government agencies, such as forestry and health, as well as competent agency heads aware of the complexity of the issues.

In our empirical analysis, we first test the proposed hypothesis, using time-series cross-section data on water quality across the globe. Second, we conduct an in-depth investigation into the political and institutional obstacles to the provision of safe drinking water in democracies by using interview and documentary data from the case of Moldova.

\subsection{Large-N}

\subsubsection{Data}

In gauging our dependent variables, we rely on a number of measures. First, we measure the degree of pollution in the water bodies using data on biochemical oxygen demand (BOD) from the World Bank (2015). BOD reflects the amount of oxygen that bacteria living in the water consume to break down organic pollutants, such as sewage or excessive amounts of dead algae caused by nitrates and phosphates coming from fertilizers, industrial waste, and landfills. This makes BOD a suitable proxy for the level of pollution in countries' freshwater resources, with high values corresponding to high levels of water pollution. The measure is comparable across countries and is available for 102 states over years 1986-2007, unbalanced. ${ }^{4}$ We weight the measure by two parameters for comparison. First, we divide it by countries' population size to receive the amount of water pollution per capita. Second, we divide it by the total volume of internal renewable water resources available in countries, measured in $10^{9}$

\footnotetext{
${ }^{3}$ Additionally, water quality to a certain degree depends on the factors outside government control, such as e.g. polluting and extractive behavior of the neighboring countries sharing a particular water body. Diffused sources of pollution make it difficult to isolate the effect of government competence on the actual outcome by concealing government efforts in delivering access to clean drinking water.

${ }^{4}$ Unfortunately, there are no data available online on BOD after 2007.
} 
$\mathrm{m}^{3}$ of average renewable flows per year, to receive the amount of pollution relative to rivers' capacity to handle it. The data on population come from Gleditsch (Gleditsch, 2011), while data on internal renewable water resources come from Food and Agriculture Organization (FAO, 2016).

Second, we gauge countries' effort to improve water quality by using the measure of the wastewater treatment levels taken from the Environmental Performance Index (Hsu et al., 2014). The measure captures the proportion of wastewater from households, municipalities, and industries that undergoes at least primary treatment ${ }^{5}$ before it is released into the water bodies, weighted by the number of people connected to the sewage network. The measure is available for 180 countries for the year 2014 and varies from 0 to 100, where higher values indicate higher levels of wastewater treatment.

The two dependent variables complement each other. While the level of wastewater treatment is an input-measure and reflects the presence of plants for treating wastewater, as well as the capacity to which they are used, BOD is an output-measure and gauges the level of actual pollution in waters, showing the effectiveness of these plants.

We measure democracy by using polyarchy index from the Varieties of Democracy project (Coppedge et al., 2016; Pemstein et al., 2015). The index reflects the extent to which electoral democracy principle is developed in countries and accounts for the degree of suffrage, freedom of expression, freedom of association, the fairness of elections, and whether the executive is appointed through popular elections. We rescale the index to take values from 0 to 10 where higher values correspond to more democratic regimes.

Our measure of the quality of government (QoG) comes from the International Country Risk Guide (ICRG, 2014) and provides an estimate of the three main aspects of QoG in countries: the extent of corruption, the strength of rule of law, and the level of bureaucratic quality. The corruption indicator captures how widespread different forms of corruption are, including patronage, nepotism, clientelism, job reservations, unofficial party funding and close ties between business and politics. The "law and order" indicator accounts for the strength of the judicial system and public obedience with the law, while the indicator gauging bureaucratic quality shows the capacity of the public administration to perform its tasks without intervention from politics and covers issues of meritocratic employment in the bureaucracies. Together, the indicators provide a comprehensive idea of the level of governmental quality in countries. The rescaled index ranges from 0 to 10 where higher

\footnotetext{
${ }^{5}$ Primary treatment includes basic processes that remove suspended soils from water and reduces BOD (Hsu et al., 2014).
} 
values refer to a higher quality of government. ${ }^{6}$

We make sure to control for relevant factors and tease out their effect on our dependent variables. First and foremost, we include gross domestic product (GDP) per capita, measured in constant 2005 US dollars (Heston et al., 2012). On the one hand, countries at higher levels of economic development tend to pollute more. On the other hand, we also expect that countries with higher income have more financial resources to address water pollution problems and build more water treatment plants. Second, we include the measure of population density and urbanization rates available from the World Development Indicators (World Bank, 2015). On the one hand, higher population density and urbanization create higher pressure on water resources; on the other hand, however, it is easier to provide social services to more densely living populations and to urbanized areas (McGuire, 2010). In our between- models, we additionally control for the area size, as it requires more effort to clean water bodies and build wastewater treatment plants if the territory is large. We also include the measure of countries' latitude to account for unobserved geographical factors (La Porta et al., 1999). In several models where our dependent variable is BOD per capita, we also add the volume of internal renewable water resources in the list of control variables to tap into the capacity of water bodies to handle pollution (FAO, 2016). However, the data on water resources are limited in availability and therefore, we only use these models as complementary to compare the effects. Summary statistics and the correlation between the variables are available in Appendix B.

\subsubsection{Method}

When testing our hypothesis with the BOD indicator as the dependent variable, we take into account both variation between countries and developments within states and use the within-between estimator, recently suggested by Bell and Jones (2015) and based on the earlier work by Bartels (2008), Rabe-Hesketh et al. (2005), and Mundlak (1978). The method allows us to use random effects by dealing with the issue of correlated errors. In particular, we include country mean of each independent variable together with its calculated deviation

\footnotetext{
${ }^{6}$ In the robustness checks, we rerun the analysis with the Freedom house/Polity IV measure from Hadenius and Teorell (2005) as an alternative indicator of democracy and a measure of corruption from the Varieties of Democracy project as an alternative measure of institutional quality. Freedom House/Polity IV indicator is an average of Freedom House and Polity IV democracy scores and has shown to perform better in terms of reliability and validity than each of the indices separately (Hadenius and Teorell, 2005). V-dem political corruption index is a composite measure of executive, legislative, judicial and public sector corruption and therefore taps upon many of the aspects of the quality of government index used in the main analysis. Results from the robustness checks are presented in Appendix D.
} 
from the mean and use the latter instead of the original raw values. Thus we obtain separate coefficients for between-country and within-country variation using the equation:

$$
y_{i t}=\beta_{0}+\beta_{1}\left(x_{i t}-\overline{x_{i}}\right)+\beta_{2} \overline{x_{i}}+\beta_{3} z_{i}+\left(u_{i}+e_{i t}\right)
$$

where $i$ is a country, $t$-year, $\beta_{0}$ is the intercept, $x$ is a vector of the independent time-varying variables, $z$ is a vector of time-invariant variables, $u$ is an error in the between-equation, and $e$ is an error in the within-equation.

When testing our hypothesis with the level of wastewater treatment as the dependent variable, we analyze the variation across countries using simple OLS regression with robust standard errors, where all independent variables are lagged 4 years: ${ }^{7}$

$$
y_{t}=\beta_{0}+\beta_{1} x_{t-4}+e
$$

where $t$ is $2014, \beta_{0}$ is the intercept, $x$ is a vector of the independent variables and $e$ is an error term.

\subsubsection{Results}

Models 1-6 in Table 1 present results from equation 1, separating between- and withinparts into different sections. ${ }^{8}$ Between-part shows the coefficients based on the analysis of the variance between countries, averaged over the time period, while within-part presents the coefficients produced in the analysis of developments within countries over time. In Models 1-4 we use the logged value of the biochemical oxygen demand per capita as our dependent variable to measure water pollution. Models 3 and 4 introduce the volume of internal renewable water resources as an additional control variable. Models 5 and 6 treat logged value of the biochemical oxygen demand weighted by the volume of internal renewable water resources as the dependent variable.

The results in models 1 and 3 show that democracy and quality of government do not seem to have independent effects on the levels of water pollution. However, when BOD is weighted by the volume of rivers in model 5 , more democracy seem to be associated with lower biochemical

\footnotetext{
${ }^{7}$ The choice of four-year lag is arbitrary. We assume that it takes time for the independent varaibles to have a measurable effect on our dependent variable, and therefore, tested our results with two-, three-, four-, and five-year lags of indpendent variables. The results are similar.

${ }^{8}$ Despite the fact that the results in the within- part are insignificant, we still include both within- and between- parts in the same table, as they are parts of the same equation and cannot be separated.
} 
oxygen demand, which is also consistent with the findings by Li and Reuveny (2006). Models 2,4 , and 6 specify that the effects of democracy and quality of government on the level of water pollution are not linear but are dependent on one another. Judging by the $\mathrm{R}^{2}$, the interaction models $(2,4$, and 6$)$ explain $6 \%$ more variance in the dependent variable compared to models where the effects of democracy and QoG are modeled as independent $(2,3$, and $5)$. The negative sign on the interaction coefficient implies that the variables decrease each other's effect on the level of water pollution when their effects are positive and increase each other's effect when their effects are negative. The results seem to only be significant for the between-part of the equation, while the results for the within-part are insignificant, implying that our models only explain variation between countries but not changes over time.

Models 7 and 8 show the results for Equation 2, where the dependent variable is the level of wastewater treatment relative to the population connected to the sewage. Higher values thus mean better performance and therefore the interpretation of the results is opposite to the previous models. The results reflect a similar picture. Model 7 shows that higher quality of government is associated with lower level of wastewater treatment, controlling for economic, demographic, and geographical factors. The effect of democracy is insignificant. Model 8 reveals that the effects of democracy and quality of government are interdependent. More quality of government seems to increase the effect of democracy on the level of wastewater treatment, while more democracy seems to intensify the effect of quality of government.

To get a more nuanced picture of how democracy and quality of government interact in their effects on water quality, we proceed by plotting their conditional marginal effects. As the results only seem to explain the differences across countries not developments over time within states, we only build graphs for the between-sample. Figure 1 presents the plots for each of the interaction models. The patterns on the figures are consistent with one another. Figures in column $a$ show the effects of democracy on water quality at different levels of quality of government, while figures in column $b$ present the effects of quality of government on water quality at different levels of democracy. The histogram overlaying the graphs shows the distribution of the variables on the $\mathrm{x}$-axis, and $\mathrm{y}$-axis on the right specifies the percentage of observations that vertical bars represent.

Plot 2a on Figure 1 shows that more democracy is associated with lower levels of biochemical oxygen demand only when QoG is relatively high and has reached the level of approximately 7.5 out 10, which is the level of Spain. The histogram on the graph shows that countries with QoG higher than 7.5 comprise around $31 \%$ of our sample. When QoG is relatively low, more democracy even seems to be associated with higher BOD (higher pollution). This relationship applies for countries that score lower than 5 on the $0-10$ QoG scale, which is the level of 
Table 1. Democracy, quality of government and water quality

\begin{tabular}{|c|c|c|c|c|c|c|c|c|}
\hline & Model 1 & Model 2 & Model 3 & Model 4 & Model 5 & Model 6 & Model 7 & Model 8 \\
\hline \multicolumn{9}{|l|}{ Between-part } \\
\hline \multirow[t]{2}{*}{ Democracy } & 0.034 & $0.367^{* * *}$ & 0.004 & $0.351^{*}$ & $-0.366^{* * *}$ & 0.375 & 0.201 & $-6.220^{* * *}$ \\
\hline & $(0.029)$ & $(0.096)$ & $(0.042)$ & $(0.125)$ & $(0.094)$ & $(0.255)$ & $(0.897)$ & $(1.602)$ \\
\hline \multirow[t]{2}{*}{ QoG } & 0.026 & $0.415^{*}$ & 0.139 & $0.524^{* * *}$ & 0.130 & $0.921^{*}$ & $6.681^{* * *}$ & -2.298 \\
\hline & $(0.080)$ & $(0.131)$ & $(0.107)$ & $(0.139)$ & $(0.214)$ & $(0.325)$ & $(1.359)$ & $(2.187)$ \\
\hline \multirow[t]{2}{*}{ Democracy*QoG } & & $-0.059^{* * *}$ & & $-0.062^{*}$ & & $-0.128^{*}$ & & $1.251^{* * *}$ \\
\hline & & $(0.016)$ & & $(0.022)$ & & $(0.042)$ & & $(0.290)$ \\
\hline \multirow[t]{2}{*}{ GDP per capita (log) } & $0.502^{* * *}$ & $0.501^{* * *}$ & $0.424^{*}$ & $0.449^{*}$ & $0.527 \dagger$ & $0.573 \dagger$ & $3.369 \dagger$ & $3.716 \dagger$ \\
\hline & $(0.132)$ & $(0.132)$ & $(0.144)$ & $(0.149)$ & $(0.310)$ & $(0.303)$ & $(1.911)$ & $(1.942)$ \\
\hline \multirow[t]{2}{*}{ Population density (log) } & 0.077 & $0.099 \dagger$ & 0.082 & 0.082 & $0.597^{* * *}$ & $0.632^{* * *}$ & $3.086^{* *}$ & $3.455^{* *}$ \\
\hline & $(0.054)$ & $(0.055)$ & $(0.059)$ & $(0.059)$ & $(0.167)$ & $(0.152)$ & $(1.414)$ & $(1.351)$ \\
\hline \multirow[t]{2}{*}{ Urban population } & -0.004 & -0.004 & -0.002 & -0.003 & -0.002 & -0.003 & $0.216^{* *}$ & $0.227^{*}$ \\
\hline & $(0.005)$ & $(0.005)$ & $(0.006)$ & $(0.005)$ & $(0.013)$ & $(0.013)$ & $(0.086)$ & $(0.083)$ \\
\hline \multirow[t]{2}{*}{ Area $(\log )$} & 0.002 & 0.030 & -0.022 & -0.056 & -0.072 & -0.068 & 1.300 & 1.051 \\
\hline & $(0.042)$ & $(0.041)$ & $(0.081)$ & $(0.094)$ & $(0.127)$ & $(0.129)$ & $(1.231)$ & $(1.202)$ \\
\hline \multirow[t]{2}{*}{ Latitude } & $1.474^{*}$ & $2.004^{* * *}$ & 0.426 & 1.381 & 2.580 & $4.408^{* *}$ & $51.283^{* * *}$ & $44.889^{* * *}$ \\
\hline & $(0.542)$ & $(0.510)$ & $(0.831)$ & $(0.926)$ & $(1.732)$ & $(1.719)$ & (11.613) & $(11.470)$ \\
\hline \multirow[t]{2}{*}{ Water resources $(\log )$} & & & 0.046 & 0.079 & & & & \\
\hline & & & $(0.049)$ & $(0.057)$ & & & & \\
\hline \multicolumn{9}{|l|}{ Within-part } \\
\hline \multirow[t]{2}{*}{ Democracy } & -0.041 & -0.040 & -0.053 & -0.054 & -0.053 & -0.055 & & \\
\hline & $(0.025)$ & $(0.025)$ & $(0.033)$ & $(0.036)$ & $(0.034)$ & $(0.038)$ & & \\
\hline \multirow[t]{2}{*}{ QoG } & -0.009 & -0.009 & -0.009 & -0.008 & -0.007 & -0.006 & & \\
\hline & $(0.025)$ & $(0.026)$ & $(0.028)$ & $(0.029)$ & $(0.029)$ & $(0.029)$ & & \\
\hline \multirow[t]{2}{*}{ Democracy*QoG } & & -0.003 & & 0.008 & & 0.012 & & \\
\hline & & $(0.012)$ & & $(0.013)$ & & $(0.014)$ & & \\
\hline \multirow[t]{2}{*}{ GDP per capita $(\log )$} & 0.165 & 0.166 & 0.197 & 0.201 & 0.219 & 0.225 & & \\
\hline & $(0.131)$ & $(0.132)$ & $(0.164)$ & $(0.167)$ & $(0.163)$ & $(0.166)$ & & \\
\hline \multirow[t]{2}{*}{ Population density (log) } & 0.407 & 0.412 & 0.423 & 0.419 & $1.304^{*}$ & $1.300^{*}$ & & \\
\hline & $(0.350)$ & $(0.351)$ & $(0.420)$ & $(0.420)$ & $(0.408)$ & $(0.409)$ & & \\
\hline \multirow[t]{2}{*}{ Urban population } & 0.016 & 0.016 & 0.016 & 0.016 & 0.017 & 0.017 & & \\
\hline & $(0.013)$ & $(0.013)$ & $(0.014)$ & $(0.014)$ & $(0.015)$ & $(0.015)$ & & \\
\hline \multirow[t]{2}{*}{ Constant } & $-3.631^{*}$ & $-6.192^{* * *}$ & $-3.120 \dagger$ & $-5.273^{*}$ & 1.943 & -3.365 & $-94.104^{* * *}$ & $-51.705^{* *}$ \\
\hline & $(1.145)$ & $(1.316)$ & $(1.606)$ & $(1.766)$ & $(2.907)$ & $(3.277)$ & $(22.192)$ & $(24.685)$ \\
\hline Observations & 750 & 750 & 618 & 618 & 618 & 618 & 128 & 128 \\
\hline$R^{2}$ between & 0.63 & 0.68 & 0.60 & 0.64 & 0.44 & 0.50 & 0.75 & 0.77 \\
\hline$R^{2}$ within & 0.10 & 0.10 & 0.11 & 0.11 & 0.21 & 0.21 & & \\
\hline Number of countries & 84 & 84 & 69 & 69 & 69 & 69 & 128 & 128 \\
\hline Year FE & yes & yes & yes & yes & yes & yes & no & no \\
\hline
\end{tabular}

Robust standard errors in parentheses, ${ }^{* * *} \mathrm{p}<0.001,{ }^{* *} \mathrm{p}<0.01,{ }^{*} \mathrm{p}<0.05,{ }^{\dagger} \mathrm{p}<0.1$. Model 1-4: DV: BOD per capita. Model 5-6: DV: BOD relative to internal renewable water resources. Model 7-8: DV: level of wastewater treatment relative to population connected to sewage. OLS for cross-country sample for 2014 with all independent variables lagged 4 years 
Tanzania. These countries comprise around $20 \%$ of the total sample. Plot $2 \mathrm{~b}$ shows that more QoG is associated with more water pollution in authoritarian regimes that score less than 4 on the 0-10 democracy scale, which was the level of Russia in the early 2000s. These authoritarian regimes comprise $17 \%$ of our all our cases. Plots $4 \mathrm{a}$ and $4 \mathrm{~b}$ echo the patterns reflected in plots $2 \mathrm{a}$ and $2 \mathrm{~b}$. However, when our dependent variable becomes weighted by the volume of the internal renewable water resources (plots 6a and 6b) the negative effect of democracy at low levels of QoG disappears, and democratic institutions seem to be associated with lower water pollution already at the levels of QoG as low as 4.8.

Plots $8 \mathrm{a}$ and $8 \mathrm{~b}$ show similar picture to the rest of the graphs, however, as the dependent variable is the level of wastewater treatment as opposed to water pollution in the previous models, the interpretation is reverse. Plot 8 a illustrates that democracy is only associated with higher levels of wastewater treatment when QoG is relatively high (higher than 6.5 out of 10). In low-QoG settings (with QoG lower than 3.5 on the 0-10 scale), more democracy even seems to be detrimental to wastewater treatment levels. Plot 8b shows that QoG is beneficial for the levels of wastewater treatment in countries scoring above 4 on the 0-10 democracy scale, which is the level of Venezuela. These democratic and semi-democratic regimes represent around $70 \%$ of our sample. In authoritarian states, QoG does not seem to play a role for the wastewater treatment levels.

In sum, the results show that democracy and quality of government have complementary effects on water quality: at low levels of quality of government, more democracy is only associated with higher water pollution. However, democracy's effect becomes positive in contexts with high QoG. Similarly, more QoG has shown to correlate with higher levels of water pollution in authoritarian regimes, but have not shown to matter in democracies. When it comes to building and using wastewater treatment plants, however, the picture becomes the opposite: QoG does not seem to matter in authoritarian regimes, while it is beneficial for the level of wastewater treatment in regimes with democratic institutions. In the patterns we found, there are four relationships that call for further exploration: how high QoG boosts the effect of democracy, how low QoG disrupts the effects of democracy or how more democracy becomes detrimental at low QoG, how authoritarian regimes with high QoG can pollute water resources more and how democratic institutions intensify the positive effect of QoG on the wastewater treatment initiatives.

To examine all patterns in depth is far beyond the scope of this paper. In our qualitative investigation, we step away from comparative perspective leaving in-depth comparisons that could help unpack the reasons behind the relatively worse or better performance across institutional configurations for future research. Instead, here we explicitly focus on the 

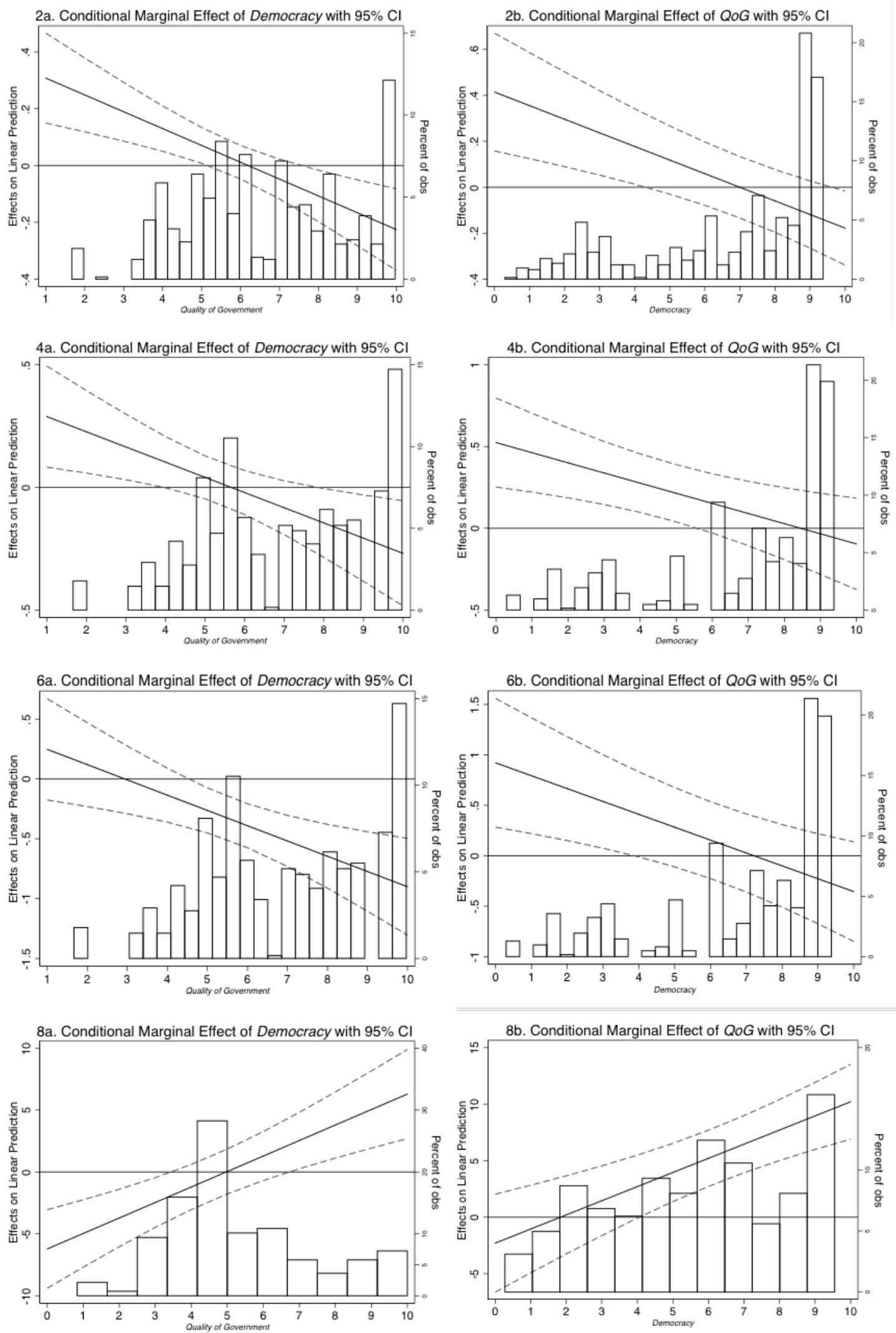

Figure 1. Conditional marginal effects of democracy and quality of government on water quality 
Table 2. Four institutional configurations

\begin{tabular}{|l|l|l|l|}
\hline \multicolumn{2}{|c|}{} & \multicolumn{2}{c|}{ QoG } \\
\cline { 3 - 4 } Democracy & High & $\begin{array}{l}\text { Democracies } \\
\text { with high QoG }\end{array}$ & $\begin{array}{l}\text { Democracies } \\
\text { with low QoG }\end{array}$ \\
\cline { 2 - 4 } & Low & $\begin{array}{l}\text { Autocracies } \\
\text { with high QoG }\end{array}$ & $\begin{array}{l}\text { Autocracies } \\
\text { with low QoG }\end{array}$ \\
\hline
\end{tabular}

performance of democratic regimes and explore the mechanisms behind one specific pattern that stands out from our findings: how weak institutional quality undermines the functioning of democracy for the delivery of safe water quality as a public good (Table 2).

\subsection{Case study}

To investigate the specific micro-mechanisms of how low quality of government can significantly hamper provision of safe drinking water in democracies, we choose a typical case, which would be representative of the group of countries that score high on democracy, low on indicators of QoG, and have a low residual in our model. The country of Moldova fits all of these conditions. Moldova scores high on democracy indicators available and at the same time has low scores on indicators of governmental quality (see Table 3). Figure 2 positions Moldova against other countries with respect to democracy and quality of government.

In the following section, we explain our case selection rationale or why Moldova offers a particularly useful ground for examining the institutional factors hampering the provision of safe drinking water in democracies.

\subsubsection{Moldova as a case}

Since establishing its independence in 1991, Moldova has emerged as one of the most pluralistic and competitive countries among the new democracies of post-Communist Eurasia, and developed strong freedom of expression (Crowther, 2013). President Voronin and his Communist party, which came to power in 2001, tried to change this and took steps to monopolize power by controlling businesses and media (Meister, 2011). However, he failed to consolidate his political rule and the widespread popular discontent in 2009 culminated in the "Twitter Revolution", which swept to power a coalition of three parties - "Alliance for European Integration" (AEI). The coalition included the Liberal-Democrats (PLDM), 
Table 3. Moldova's scores on the indicators of Democracy and Quality of Government

\begin{tabular}{|c|c|c|c|c|c|}
\hline Democracy Indicator & $\begin{array}{l}\text { Moldova's } \\
\text { score }\end{array}$ & $\begin{array}{l}\min - \\
\max \end{array}$ & QoG indicators & $\begin{array}{l}\text { Moldova's } \\
\text { score }\end{array}$ & $\begin{array}{l}\min - \\
\max \end{array}$ \\
\hline $\begin{array}{l}\text { Polyarchy Index, } \\
\text { V-Dem }\end{array}$ & 0.72 & $0-1$ & $\begin{array}{l}\text { Quality of Government, } \\
\text { ICRG }\end{array}$ & 0.44 & $0-1$ \\
\hline $\begin{array}{l}\text { Political rights, } \\
\text { Freedom House }\end{array}$ & 3 (free) & $7-1$ & $\begin{array}{l}\text { Control of Corruption, } \\
\text { World Bank }\end{array}$ & -0.69 & $-2.5-2.5$ \\
\hline $\begin{array}{l}\text { Civil liberties, } \\
\text { Freedom House }\end{array}$ & 3 (free) & $7-1$ & $\begin{array}{l}\text { Rule of Law, } \\
\text { World Bank }\end{array}$ & -0.39 & $-2.5-2.5$ \\
\hline Polity IV & 9 & $0-10$ & $\begin{array}{l}\text { Government Effectiveness, } \\
\text { World Bank }\end{array}$ & -0.64 & $-2.5-2.5$ \\
\hline Freedom House/Polity IV & 8.08 & $0-10$ & $\begin{array}{l}\text { Corruption Perception } \\
\text { Index }\end{array}$ & 29 & $100-1$ \\
\hline $\begin{array}{l}\text { Dichotomous index, } \\
\text { Cheibub }\end{array}$ & 1 & $0-1$ & $\begin{array}{l}\text { Political Corruption Index, } \\
\text { V-Dem }\end{array}$ & 0.65 & $1-0$ \\
\hline
\end{tabular}

the Democrats (DM), and the Liberals (LM). In the parliamentary elections following the revolution, the parties ran independently. But since none of them gathered enough votes to form a government, they decided to create an alliance, and with the joint 59 seats pushed the Communist party in opposition (42 seats). This gave rise to a pluralistic political climate and media freedom in the country, and for this reason, we focus our analysis specifically on the post-2009 period.

Despite the predominantly pluralistic nature of politics, however, Moldova continues to suffer from low quality of government: weak rule of law, low quality of administrative apparatus and particularly high levels of corruption (see Appendix B). Unsurprisingly, Moldovan population also continues to lack access to safe drinking water. The problem is double-fold: (1) lack of water supply, and (2) poor water quality. The access to waterpipe system is around 80 percent in the cities and 15 percent in the villages (Botnaru, 2014). However, neither of those connected to water pipes have access to safe drinking water. Water available to citizens from the local sources is often contaminated either by the microbial pollution or by high levels of nitrates. Duca (2014) shows that about 1.9 million people are exposed to pollutants from water, that is, more than a half of the country's 3.5 million population.

One common explanation for the underperformance of democracies in the provision of safe drinking water is the lack of financial and technical resources. Moldova is indeed one of the poorest countries in Europe with GDP per capita of only USD 1525 for the year 2009. However, absence of funding alone cannot account for this lingering problem, since many 


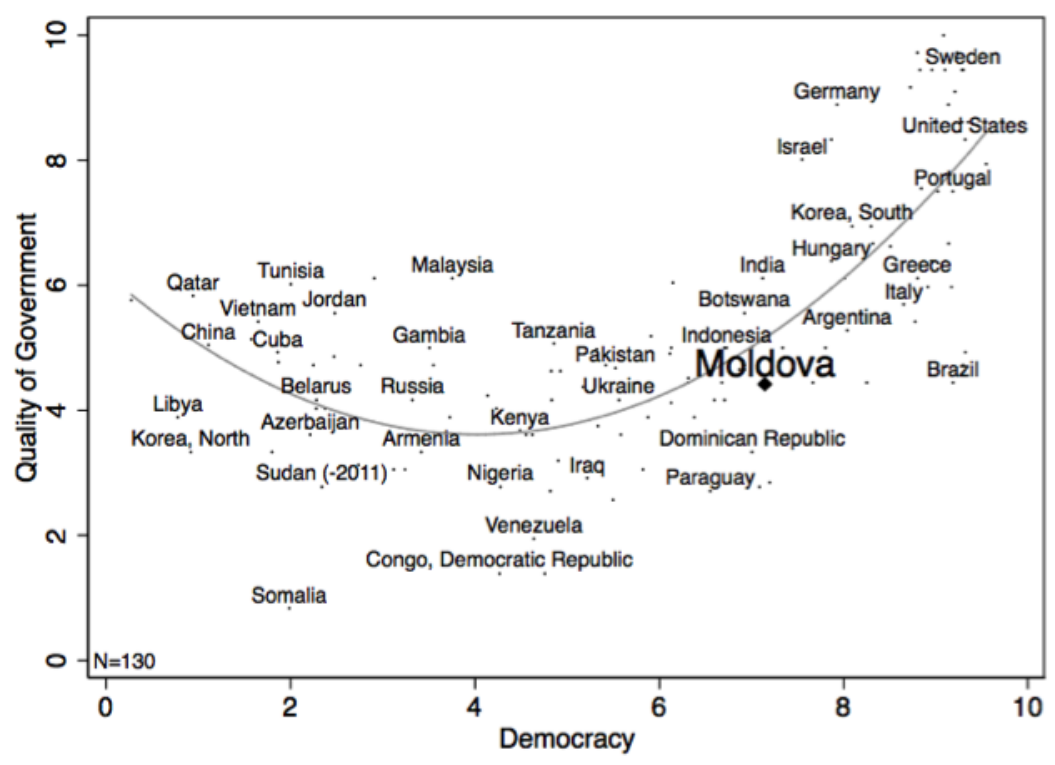

Figure 2. Moldova in the relationship between democracy and quality of government

international donors, including Swiss and Austrian Development Agencies, US AID, German Society for International Cooperation and the European Union, have provided authorities with extensive budgetary and technical support to remedy the situation. Despite this, however, citizens' access to safe drinking water has remained limited, and specialists continue to warn about the health risks of drinking water from the conventional sources (authors' interview with an official from the Ministry of Environment, April 2016).

This combination of democratic qualities and availability of funds, with the persistence of water problems, makes Moldova a particularly opportune case to examine how the specific micro-mechanisms of low governmental quality hamper citizens' access to one of the essential public goods. To closely investigate these mechanisms, we have conducted fieldwork in Moldova's capital Chisinau throughout March-April 2016. To collect an in-depth and detailed data, we have carefully studied various government memorandums and conventions on water management, including the Moldovan Water Supply and Sanitation Strategy 2012, Moldovan Water Law of 23 December 2011 (\#272), Moldovan Law on public service of water supply and the sewerage of 13 December 2013 (\#303), Moldovan strategy on water supply and sanitation for 2014-2028 of 20 March 2014 (\#199). We also conducted 25 semi-structured face-to-face interviews with some of the key stakeholders. The major stakeholders in the water management include the Ministry of Environment, Ministry of Healthcare, Ministry of Regional Development and Construction, non-governmental organizations, scientific com- 
munity, and the international donor organizations, which provide extensive financial and technical assistance for the water management reform. During our fieldwork, we aimed to get insights from all of these key actors. We interviewed top-level government officials, including one current and two former ministers, one deputy minister, as well as mid-level bureaucrats from the three ministries. We also interviewed 6 representatives from donor and diplomatic community, 5 heads of civil society organizations and environmental NGOs, 2 independent consultants, 3 academics, and 2 investigative journalists. Given the sensitivity of data, the interviewees were promised anonymity, and all the important details were triangulated with other sources to warrant their accuracy/validity.

\subsubsection{Water management challenges in Moldova}

After the dramatic events of the 2009 'Twitter revolution', the Alliance for European Integration (AEI) took the reins of power and pledged to undertake systematic reforms, aiming at fighting corruption, improving the quality of life of Moldovans, and bringing the country closer to the European Union governaning standards. The Democratic Party (PDM) was backed by the second wealthiest businessman in the country, Vlad Plahotniuc, while the Liberal Democratic Party (PLDM) was funded, and also chaired, by the third richest businessmen, Vlad Filat. The third, and smaller member of the coalition, the Liberal Party (PL) represented those voters that favored joining Romania. The tripartite coalition agreement, signed in December 2010, defined the allocation of government offices between the parties. Among other ministries, the Ministry of Environment was assigned to the PL, the Ministry of Regional Development and Construction to the PDM, while the Ministry of Healthcare to the PLDM.

The outspokenly pro-European and reform-oriented approach of the alliance led Western donors to significantly step up the financial and technical assistance, which among other issues aimed at improving citizens' access to safe drinking water. This policy domain alone in 2012 received 109 million Euros from external donors (State Chancellery of Moldova, 2013, 18). The Brussels was particularly active in this area and provided substantial support to help Moldova get closer to European standards and particularly to the EU's Water Framework Directive. The other donors also included the World Bank, as well as the United States-, the Swiss-, the Austrian-, and the German Development Agencies.

Provision of safe drinking water fell within the responsibility of three different ministries: The Ministry of Environment (PL), the Ministry of Regional Development and Construction (PDM), and the Ministry of Healthcare (PLDM). The initial expectation among the donors 
was that functions of these bodies would complement one another. According to the experts of water management, Ministry of Regional Development should have been in charge of the water supply, Ministry of Environment - in charge of improving the water quality, while the laboratory within the Ministry of Healthcare would keep monitoring the water quality.

Unlike these expectations, however, the actual division of responsibilities included a lot of overlapping functions. Formally, the Ministry of Environment became the line ministry in charge of water supply and sanitation, however, Ministry of Regional Development was also assigned some role in this. Soon it became clear that both the environmental and regional development ministries started competing with each other and promoted a lot of projects that expanded the water pipeline network into the villages. However, these pipes continued to provide water that was either contaminated by high level of nitrates or microbial pollution, since no authority engaged in improving water quality. As an environmental expert from the local NGO remarked:

"The Ministry of Environment does not want to delegate the water supply and sanitation to the ministry of regional development because they will lose a lot of PR. When you open a pipeline this is TV [sic]. On the other hand, water quality management is related to river management, which is more difficult... Pipeline you manage in one month, river management takes years." (Authors' interview, April 2016, Chisinau)

Another informant from the environmental watchdog similarly highlighted the politicians' excessive focus on expanding the water supply network, explaining this with the fact that "pipelines bring votes" (Authors' interview, April 2016, Chisinau). In private interviews, a number of donors noted that they were not happy with the duplication of functions. But also remarked that they could not do much since "it all comes from politics, pure politics", pointing to the fact that all parties were interested in gaining immediate publicity, and votes (Authors' interview, April 2016, Chisinau).

A former high-ranking official from the Environmental Ministry also corroborated this fact and named "a lot of patchwork" and the absence of coordination between the ministries as the major obstacle for improving water quality in Moldova. "[T] his is not a healthy competition because they [ministries] are competing in the same village without following the established ruled and guidelines" (Authors' interview, April 2016, Chisinau).

Similar to many young democracies, Moldova, since gaining independence, has been suffering from a lack of party institutionalization. Parties are not anchored in the conventional societal cleavages but instead are built around powerful individuals. The grassroots contribution to 
parties is absent and parties almost entirely depend on the financial resources of their wealthy backers. Business interests, therefore, have been especially pronounced during the tenure of the AEI, and various watchdog organizations continued to report about the adoption of laws favoring entrenched special interests.

In 2012, the Ministry of Transport and Road Infrastructure initiated a law in Parliament, which envisioned extraction of gravel and sand from the riverbeds, with the declared aim of deepening the fairway of rivers and allowing large vessels to navigate in Dniester and Prut rivers. The environmental NGOs strongly criticized the bill and claimed that legalizing extraction of sand and gravel would be destructive for the river ecosystems, as they would lose their self-cleaning qualities. Instead, the civil society organizations pointed to the commercial interests of the construction companies and claimed that the already existing illegal business of extracting raw materials would now be legalized "under the guise of navigation" (Iaşcenco and Barbier, 2015). "It's clear why. The companies involved in the illegal extraction of sand and gravel make big money from the sale of these materials," a representative from an environmental NGO remarked (Ibid). A former high-ranking official from the Environmental Ministry explained that the Moldovan rivers were not suitable for the large vessels, and corroborated the existence business interests behind the draft law:

"It [sand and gravel extraction] is a huge business. One cubic meter of sand is sold for 10 euros, and they are extracting thousands and thousands each day. I saw the process, I have made the evaluation: [they make] between 50000 and 100 000 euros each day." (Authors' interview, April 2016, Chisinau)

The environmental NGOs with the financial support of the foreign donors (US embassy) initiated a large-scale campaign to raise awareness among the politicians and the public about the destructive effect of the bill, and how it would lead to the degradation of the main sources of drinking water in the country. The Parliament nonetheless adopted the law, and as the civil society organizations lamented:

"[D]espite of [sic] well developed legal framework on public participation on governmental and parliamentary levels, it is very difficult now to protect the public interests in conditions of total corruption of the political majority. [...] We observed many times that both government and parliament are ready to violate their own laws and rules in favor of existing criminal groups." (Eco-Tiras, 2013)

Among various sources of water pollution, experts also pointed to the established practice among big business enterprises, such as wine and sugar producers, to discharge the industrial wastewater to rivers. "Fines are very low, so it's easier to pay the fine of approximately 20000 
EUR, then to build the wastewater treatment plant that costs 2 million Euros" - an informant from the scientific community explained (Authors' interview, April 2016, Chisinau). Other informants, however, also pointed to the close connections between the business enterprises and the politicians, and as a consequence - privileged treatment of many of these companies. "Big companies often belong to parties in the government... And they don't care - inspectors cannot touch them. Inspectors are told, here you can check, here you cannot, so inspectors are themselves afraid" (Authors' interviews with a chair of an environmental NGO and an environmental scientist, April 2016, Chisinau). In an anonymous interview, an inspector from the environmental inspectorate also confirmed the fact that they "cannot touch some people", otherwise even risking being fired (Authors interview, April 2016, Chisinau). Developing strong inspectorate in itself is not a priority. It receives little funding, despite strong support from the donors: "No cars, and even for those few cars, there is no budget for fuel, no boats to catch poachers, despite a lot of funding from donors" (Authors' interview, April 2016, Chisinau).

However, neither the small enterprises nor other actors contributing to the pollution of rivers, get punished given the pervasiveness of petty corruption among the administrative bodies. As an inspector explained, inspectorates continue to go underfunded and many inspectors have no other choice than to supplement their low salaries with an additional income through bribes.

The presence of petty corruption significantly accelerated the illegal logging problem. Forests are one of the most effective tools to maintain the water quality since trees serve as natural sponges, collecting and filtering rainfall (Hamilton, 2008). Deforestation therefore significantly contributes to the pollution of water sources. In the recent years, however, Moldova has continued to witness a sharp decrease of the forest areas, partly due to the illegal logging. In 2016, an investigation by the State Audit Office in the Forestry Agency Moldsilva revealed that the forest security had failed to fulfill its obligation of protecting forest from poachers. Investigative journalists, as well as environmental experts, have been unanimously pointing to rampant corruption in the agency, and particularly among the forest guards, as the major reason behind the massive deforestation. "It is quite obvious the fact that illegal deforestation takes place with the silent consent of officials who are rewarded for it" (Crime Moldova (2016), emphasis added; Authors' interviews, April 2016, Chisinau).

Presence of petty corruption, however, is not the only reason behind the ineffectiveness of bureaucracy in dealing with water management problems. Politicization of civil service remains a prevalent problem in Moldova, and several informants argued that given the political uncertainty, governing parties have been much more interested in filling 'their' 
respective ministries with loyal - rather than professional - cadres. As an expert from the donor community explained:

"You see them [bureaucrats] working in a position that does not fit their qualifications and abilities... they are obliged to fulfill [tasks of] their superior who put them in this position. You see it in the [environmental] ministry; you see it in the agencies. The most outspoken and reform-minded people were dismissed, and the new people are implementing agenda of their superiors [sic]." (Authors' interview, April 2016, Chisinau)

Another expert from the donor organization added:

“[...] there is a necessity for more potential because when you select people by political criteria you could not have a good productivity [...]. Please visit the [web-] site of the ministry and look [for] the CV. There should not only be the names. [...] There should be CVs. [E]ven in the communist time, one time in three years they had to pass [...] functional analysis, how the people comply with their duties. [...] Now they forgot about it [...]." (Authors' interview, April 2016, Chisinau)

High staff turnover and appointment of non-technical personnel to the positions requiring technical knowledge led to the continuous loss of institutional memory. Low salaries and job insecurity in the public service further exacerbated this problem, as many well-trained cadres opted to leave for private sector (Authors' interview with an expert providing training in water management to public servants, April 2016, Chisinau). Politicization of public service and loss of institutional memory have therefore significantly disrupted the process of translating donor-funded capacity-building programs into concrete policy actions aimed at improving water quality.

Admittedly, the media freedom remained high in the country and investigative journalists brought various large-scale corruption cases into the limelight (including the cases of gravel and sand extraction business, and illegal logging problem in Moldsilva). However, very few of these cases were addressed or investigated due to the continuous politicization of law-enforcement bodies. As the secret annex to the coalition agreement, leaked in 2012, revealed, leaders of the AEI divided supposedly impartial institutions such as Judiciary, Anti-Corruption Centre, and Prosecutor's office along the partisan lines. This offset the system of checks and balances.

At the outset, fragmentation of power between three parties in the alliance raised hopes for the emergence of strong checks and balances. But paradoxically the coalition agreement 
thwarted it, as parties in power opted to focus on the short-term political and economic benefits of politicized institutions, instead of the long-term benefits of investing in impartial courts, and other law enforcement bodies. As a result, even those big businesses or officials, exposed for contributing to water pollution, frequently avoided being held accountable for their actions, given the absence of impartial law-enforcement bodies:

"The division of spoils between the parties has created a system of pseudo "checks and balances" that in fact leaves no top officials liable for misbehavior. When corruption cases do reach the courts, frequently they are viewed as selective retribution against opponents." (Global Security, 2016)

The law prescribes that decision-makers should consult scientific community regarding such complex programs as water management, however, the academia does not seem to have much influence over the political decisions. Suggestions and programs from the Academy of Sciences seem "to stand on the shelves for years without attention", according to the interview with a representative from the academia. After 2009, politicians seem to take opinions of the Academy less and less into consideration and even consider closing it:

"During the last three years, our financial support dropped by two times. We feel the pressure from the oligarchs. One of the main arguments to why they want to close the Academy is that it is not beneficial for them to have someone telling them what to do." (Authors' interview, April 2016, Chisinau)

\section{Discussion and conclusions}

The aim of the paper has been to investigate the relationship between democracy and quality of government in their effects on water quality as an example of a public good. While the level of democracy determines the rules of preference aggregation in the decision-making, governmental quality shapes implementation of these decisions, and we hypothesized that these two sets of political institutions interact in determining public service delivery. We

performed a nested analysis and first tested our hypothesis using time-series cross-sectional data on water quality in countries around the globe. Afterwards, we conducted a study of a typical case to tease out and illustrate the micro-mechanisms at work behind one of the relationship patterns.

The large- $\mathrm{N}$ analysis has shown that democratic institutions do not seem to always be beneficial for securing high water quality. The findings rather support the theoretical expectations that 
the effect of democracy on water quality depends on countries' ability to implement tasks and deliver public services. More democracy seems to benefit water quality only when quality of government is relatively high. When quality of government is low, more democracy only seems to be associated with higher pollution in countries' inland waters.

In-depth investigation of Moldova as a typical case - a democracy with low governmental quality - revealed the micro-mechanisms of how poor institutional quality can disrupt the positive effects of democracy. Democracies with weak quality of government seem to be dominated by short time horizons, where there is no place for long-term commitments, such as raising and maintaining high water quality. As the analysis revealed, when it comes to people's access to safe drinking water, democratic leaders with short time horizons tend to put emphasis on access to water rather than safety of water, investing more into building water pipes instead of using these resources to address water pollution and safeguard actual quality of water.

The analysis also showed that both petty and grand corruption erode the democratic political system. The latter allows business interest to step in and influence decision-making, distracting attention of the politicians from public goods provision and serve private interests instead. In the case of water management, public interest and the interest of businesses seem to clash and with the dominance of the latter in the political decision-making, the interests of the public suffer. Petty corruption in public administration undermines compliance, and in the case of Moldova, it led to poor monitoring and inspections resulting in extensive illegal logging that contributed to the poor water quality in local rivers. Politicization of civil service seems to have also negatively affected the performance of bureaucracies and increased the staff turnover. This led to the loss of institutional memory, which hampered implementation of such long-term projects as reaching safe drinking water quality levels.

Another mechanism that seems to disrupt the functioning of democratic institutions in water provision is insufficient level of checks and balances. In the case of Moldova, despite the seemingly fragmented government and strong media freedom, the system of checks and balances is absent, and business representatives and officials who are responsible for illegal actions leading to higher water pollution, do not face charges, due to the lack of impartial judicial system. The voice of the scientific community who is supposed to guide politicians in decision-making regarding water management also seems to be regularly silenced.

Other findings revealed during the large- $\mathrm{N}$ analysis show that authoritarian regimes with high quality of government pollute water more than authoritarian countries with low QoG. For example, Yemen and Azerbaijan, which both seem to have low QoG, have lower levels of 
water pollution than Qatar and Saudi Arabia, which score higher on QoG indicators. First, it might seem that these findings can be attributed to oil production and higher economic development which is known to contribute to higher pollution until a certain point (see e.g., Grossman and Krueger, 1994), however, these effects should have been taken care of in our models when we control for countries' level of GDP per capita. We suggest that the underlying micro-mechanisms behind this relationship should be investigated in more detail in the further research.

The contribution of the paper is two-fold. First, the findings offer an important specification to the previous research on democracy and public goods provision: more democracy seem to only be beneficial for the delivery of public goods when the quality of institutions shaping implementation of public policies is sufficient enough to execute the official goals. When institutional quality is low, more democratic states seem to provide even fewer public goods to its citizens than less free political systems. These findings do not imply that democracy is unimportant, but rather that its positive effects should be seen as dependent on the capacity of the state to implement its official goals, shaped by the quality of institutions guiding such implementation. The second contribution of the paper - the qualitative investigation of the micro-mechanisms behind the relationship on the typical case of Moldova - revealed that institutions specifically detrimental to the performance of democracies in public goods provision include grand and petty corruption, poorly designed and inefficient public administration, and lack of checks and balances. Combined with instability in the government, these institutions both hamper implementation of public policies and adoption of public policies by stimulating short time horizons in the political system, which guide choices of the public officials away from the provision of universal public goods in favor of private gains that benefit them in the short term. 


\section{References}

Acemoglu, D. and Robinson, J.A. (2006) Economic origins of dictatorship and democracy. Cambridge University Press.

Acemoglu, D. and Robinson, J.A. (2012) Why nations fail: the origins of power, prosperity, and poverty. New York: Crown Publishers.

Bartels, B. (2008) Beyond‘ fixed versus random effects': a framework for improving substantive and statistical analysis of panel, time-series cross-sectional, and multilevel data. The Society for Political Methodology, 1-43.

Bäck, H. and Hadenius, A. (2008) Democracy and State Capacity: Exploring a J-Shaped Relationship. Governance, 21(1) 1-24.

Bell, A. and Jones, K. (2015) Explaining fixed effects: Random effects modeling of time-series cross-sectional and panel data. Political Science Research and Methods, 3(01) 133-153.

Boräng, F., Jagers, S.C. and Povitkina, M. (2016) Political determinants of electricity provision in small island developing states. Energy Policy, 98 725-734.

Botnaru, P. (2014) In Moldova, poor water supply exposes villagers to epidemics.

Bueno de Mesquita, B. (2003) The logic of political survival. Cambridge, Mass. ; London: MIT Press.

Charron, N. and Lapuente, V. (2010) Does democracy produce quality of government? European Journal of Political Research, 49(4) 443-470.

Charron, N. and Lapuente, V. (2011) Which Dictators Produce Quality of Government? Studies in Comparative International Development, 46(4) 397-423.

Coppedge, M., Gerring, J., Lindberg, S.I., Skaaning, S.-E., Teorell, J., Altman, D., Bernhard, M., Fish M., S., Glynn, A., Hicken, A., Knutsen, C.H., Marquardt, K., McMann, K., Miri, F., Paxton, P., Pemstein, D., Staton, J., Tzelgov, E., Wang, Y.-t. and Zimmerman, B. (2016) V-Dem [Country-Year/Country-Date] Dataset v6.2 Varieties of Democracy (V-Dem) Project (ed.).

Cornell, A. (2014) Why Bureaucratic Stability Matters for the Implementation of Democratic Governance Programs. Governance, 27(2) 191-214.

Crime Moldova (2016) Moldsilva Agency or of a well-rooted corruption. Crime Moldova.

Crowther, W. (2013) Moldova. In: Sten Berglund, Joakim Ekman, Kevin Deegan-Krause, 
Terje Knutsen (eds.) The handbook of political change in eastern europe. 3rd edition Edward Elgar Publishing,

Dahlström, C., Lindvall, J. and Rothstein, B. (2013) Corruption, bureaucratic failure and social policy priorities. Political Studies, 61(3) 523-542.

Damania, R., Fredriksson, P.G. and List, J.A. (2003) Trade liberalization, corruption, and environmental policy formation: theory and evidence. Journal of Environmental Economics and Management, 46(3) 490-512.

Deacon, R.T. (2009) Public good provision under dictatorship and democracy. Public Choice, 139(1-2) 241-262.

Duca, G. (2014) Management of Water Quality in Moldova. Springer International Publishing.

Eco-Tiras (2013) The project to improve the environmental rule of law in Moldova.

Evans, P. and Rauch, J.E. (1999) Bureaucracy and growth: A cross-national analysis of the effects of 'Weberian' state structures on economic growth. American sociological review, $748-765$.

FAO (2016) AQUASTAT Main Database.

Fukuyama, F. (2011) The origins of political order: From prehuman times to the French Revolution. New York: Farrat, Straus; Giroux.

Fukuyama, F. (2013) What Is Governance? Governance, 26(3) 347-368.

Gerring, J., Bond, P., Barndt, W.T. and Moreno, C. (2005) Democracy and economic growth: A historical perspective. World Politics, 57(03) 323-364.

Gerring, J., Thacker, S.C. and Alfaro, R. (2012) Democracy and human development. The Journal of Politics, 74(01) 1-17.

Gleditsch, K.S. (2011) Expanded Trade and GDP Data.

Global Security (2016) Moldova - Corruption. Global Security.

Grossman, G.M. and Krueger, A.B. (1994) Economic growth and the environment. National Bureau of Economic Research.

Hadenius, A. and Teorell, J. (2005) Assessing Alternative Indices of Democracy. CEGM Working Papers 6, IPSA, August 2005,

Haggard, S. (1991) Inflation and Stabilization. In: Gerald M Meler (ed.) Politics and policy making in developing countries: Perspectives on the new political economy. San Francisco: 
ICS Press, 233-249.

Hamilton, L.S. (2008) Forests and water: a thematic study prepared in the framework of the Global Forest Resources Assessment 2005. 78.

Hanson, J.K. (2015) Democracy and State Capacity: Complements or Substitutes? Studies in Comparative International Development, 50(3) 304-330.

Helliwell, J.F. (1994) Empirical linkages between democracy and economic growth. British journal of political science, 24(02) 225-248.

Heston, A., Summers, R. and Aten, B. (2012) Penn World Table Version 7.1 Income Center for International Comparisons of Production, Prices (eds.).

Hicken, A. (2011) Clientelism. Annual Review of Political Science, 14 289-310.

Hsu, A., Emerson, J., Levy, M., Sherbinin, A. de, Johnson, L., Malik, O. and Jaiteh, M. (2014) The 2014 Environmental Performance Index.

Huntington, S.P. (1968) Modernization and corruption. In: Arnold J Heidenheimer, Michael Johnston, Victor LeVine (eds.) Political order in changing societies. New Brunswick: Transaction Publishers, 377-388.

Huntington, S.P. (1991) The third wave: democratization in the late twentieth century. 4. Norman: University of Oklahoma Press.

Iaşcenco, T. and Barbier, N. (2015) Illegal sand extraction from the Nistru and Prut Rivers: some get wealthy while the country has losses. Chisinau: Centre for Investigative Journalism of Moldova 'Anticoruptie'.

ICRG (2014) A Business Guide to Political Risk for International Decisions. New York: The PRS Group. International Country Risk Guide.

Keefer, P. (2007) Clientelism, Credibility, and the Policy Choices of Young Democracies. American Journal of Political Science, 51(4) 804-821.

Kitschelt, H. (2000) Linkages between citizens and politicians in democratic polities. Comparative Political Studies, 33(6-7) 845-879.

Knutsen, C.H. (2013) Democracy, State Capacity, and Economic Growth. World development, $431-18$.

La Porta, R., Lopez-de-Silanes, F., Shleifer, A. and Vishny, R. (1999) The quality of 
government. Journal of Law, Economics, and organization, 15(1) 222-279.

Lake, D.A. and Baum, M.A. (2001) The invisible hand of democracy: political control and the provision of public services. Comparative Political Studies, 34(6) 587-621.

Li, Q. and Reuveny, R. (2006) Democracy and Environmental Degradation. International Studies Quarterly, 50(4) 935-956.

Lieberman, E.S. (2005) Nested Analysis as a Mixed-Method Strategy for Comparative Research. American Political Science Review, 99(03) 435-452.

López, R. and Mitra, S. (2000) Corruption, Pollution, and the Kuznets Environment Curve. Journal of Environmental Economics and Management, 40(2) 137-150.

McGuire, J.W. (2010) Wealth, health, and democracy in East Asia and Latin America. Cambridge University Press.

McGuire, M.C. and Olson, M. (1996) The economics of autocracy and majority rule: the invisible hand and the use of force. Journal of economic literature, 34(1) 72-96.

Meister, S. (2011) A Turning Point for Moldova? A challenge for the EU and Moldova. DGAP analyse May 2011, 3.

Miller, G. (2000) Above Politics: Credible Commitment and Efficiency in the Design of Public Agencies. Journal of Public Administration Research and Theory, 10(2) 289-328.

Min, B. (2015) Power and the Vote: Elections and Electricity in the Developing World. Cambridge University Press.

Mundlak, Y. (1978) On the pooling of time series and cross section data. Econometrica: journal of the Econometric Society, 69-85.

Pemstein, D., Marquardt, K., Tzelgov, E., Wang, Y.-t. and Miri, F. (2015) The V-Dem Measurement Model: Latent Variable Analysis for Cross-National and Cross-Temporal ExpertCoded Data.

Przeworski, A. (2000) Democracy and development: political institutions and material wellbeing in the world, 1950-1990. Cambridge: Cambridge University Press.

Rabe-Hesketh, S., Skrondal, A. and Pickles, A. (2005) Maximum likelihood estimation of limited and discrete dependent variable models with nested random effects. Journal of Econometrics, 128(2) 301-323.

Ross, M. (2006) Is democracy good for the poor? American Journal of Political Science, 
$50(4) 860-874$.

Rothstein, B. (1998) Just institutions matter: the moral and political logic of the universal welfare state. Cambridge University Press.

Rothstein, B. (2011) The quality of government: corruption, social trust, and inequality in international perspective. Chicago: University of Chicago Press.

Rothstein, B. and Teorell, J. (2008) What Is Quality of Government? A Theory of Impartial Government Institutions. Governance, 21(2) 165-190.

Rothstein, B., Samanni, M. and Teorell, J. (2012) Explaining the welfare state: power resources vs. the Quality of Government. European Political Science Review, 4(01) 1-28.

Sen, A. (1999) Development as freedom. New York: Oxford University Press.

Sikkink, K. (1991) Ideas and institutions: developmentalism in Brazil and Argentina. New York: Cornell University Press.

State Chancellery of Moldova (2013) Development Cooperation - 2012 Annual Report. Chisinau: State Chancellery of Moldova.

Walton, G.W. (2013) Is all corruption dysfunctional? Perceptions of corruption and its consequences in Papua New Guinea. Public Administration and Development, 33(3) 175-190. World Bank (2015) World Development Indicators, the World Bank.

Zarazaga, R.S. (2014) Brokers Beyond Clientelism: A New Perspective Through the Argentine Case. Latin American Politics and Society, 56(3) 23-45. 


\section{Appendix A. Interview questions}

1. We are interested in the reforms in Moldova from 2009 onwards after the Alliance came to power. Could you give us a general overview of the reforms in the water management sector? What was the reform about?

2. What is the role of your organization in supporting the reform (to donor communities)

3. What are the major problems/obstacles in implementing water management reform?

4. What are the major sources of pollution in rivers? Who pollutes?

5. Are there limitations on (a) polluting industries and regulations on (b) agricultural practices that might effect pesticides/accumulation of chemicals in water bodies.

6. If yes, who monitors the process? Are there:

1) Legal framework

2) Inspectors, who can monitor compliance?

3) What is inspectorate's capacity to measure? Do they have the necessary technology/labs?

4) Are there fines for pollution?

5) How does enforcement process looks like?

If the interviewees mention unwillingness to enforce:

7. Where does the unwillingness come from? Does it stem from the political/business interests? Do politicians have disincentives to uphold laws because of the:

1) stake in businesses;

2) political funding coming from businessmen in industry;

3) they just don't know/have ordinance.

8. What are the impediments from the administrative side in implementing the reform? Mention:

- having enough staff

- the level of training of the staff

- ability to retain qualified staff (salary/motivation)

- having the necessary technical equipment to conduct their job: - as basic as computers and printers, - and more advanced - monitoring equipment and lab. equipment

- having access to information about the state of the environment:

- having someone gathering the information

- does those who gather information share it?

- having a unified measurement system for every issue (e.g., same measure for measuring water quality in Prust and Danube to compare)

- coordination and communication between different agencies responsible for the same issue

- how does corruption manifest itself? 


\section{Appendix B. Summary statistics and correlation be- tween the variables}

Table B.1. Summary statistics for the years of the dependent variable availability. $\mathrm{BOD}$ as the dependent variable

\begin{tabular}{|c|c|c|c|c|c|c|}
\hline Variable & Obs & $\mathrm{N}$ of countries & Mean & Std. Dev. & Min & $\operatorname{Max}$ \\
\hline BOD per capita & 953 & 102 & 7.61 & 4.62 & 0.01 & 22.47 \\
\hline BOD per capita $(\ln )$ & 953 & 102 & 1.70 & 1.03 & -5.12 & 3.11 \\
\hline $\mathrm{BOD} /$ water resources $(\ln )$ & 722 & 82 & 7.46 & 1.90 & 1.03 & 11.65 \\
\hline QoG, rescaled & 826 & 89 & 6.79 & 2.13 & 0.97 & 10.00 \\
\hline Democracy. V-dem. rescaled & 868 & 96 & 6.54 & 2.68 & 0.29 & 9.43 \\
\hline Freedom House/Polity IV & 953 & 102 & 7.40 & 2.99 & 0.25 & 10.00 \\
\hline Corruption, V-dem, rescaled & 868 & 96 & 4.01 & 2.88 & .09 & 9.46 \\
\hline GDP per capita & 953 & 102 & 15040.14 & 13541.51 & 425.51 & 101078.00 \\
\hline GDP per capita $(\ln )$ & 953 & 102 & 9.10 & 1.18 & 6.05 & 11.52 \\
\hline Population density & 953 & 102 & 222.16 & 763.93 & 1.59 & 6602.30 \\
\hline Population density (ln) & 953 & 102 & 4.26 & 1.32 & 0.46 & 8.80 \\
\hline Urban Population & 953 & 102 & 61.53 & 21.52 & 10.24 & 100.00 \\
\hline Land area & 953 & 102 & 756941.10 & 2193357.00 & 320.00 & 16400000.00 \\
\hline Land area $(\ln )$ & 953 & 102 & 11.82 & 2.03 & 5.77 & 16.61 \\
\hline Latitude & 953 & 102 & 0.41 & 0.19 & 0.01 & 0.71 \\
\hline $\begin{array}{l}\text { Internal renewable } \\
\text { water resources }\end{array}$ & 722 & 82 & 263.16 & 605.88 & 0.05 & 2850.00 \\
\hline
\end{tabular}

Table B.2. Summary statistics for the years of the dependent variable availability. Level of wastewater treatment as the dependent variable

\begin{tabular}{lrrrrr}
\hline \hline Variable & Obs & Mean & Std. Dev. & Min & Max \\
\hline Wastewater treatment & 178 & 24.88 & 31.41 & 0.00 & 99.65 \\
QoG, rescaled & 138 & 5.37 & 2.02 & 0.83 & 10 \\
Democracy, V-dem, rescaled & 161 & 5.64 & 2.54 & 0.27 & 9.55 \\
Freedom House/Polity IV & 178 & 6.49 & 3.09 & 0.25 & 10.00 \\
Corruption, V-dem & 161 & 5.22 & 2.80 & 0.09 & 9.40 \\
GDP per capita & 178 & 11903.90 & 14037.21 & 273.15 & 97904.79 \\
GDP per capita (ln) & 178 & 8.70 & 1.27 & 5.61 & 11.49 \\
Population density & 178 & 171.37 & 571.03 & 1.75 & 7231.77 \\
Population density (ln) & 178 & 4.14 & 1.36 & 0.56 & 8.89 \\
Urban Population & 177 & 55.85 & 22.95 & 9.09 & 100.00 \\
Land area & 178 & 725547.50 & 1911604.00 & 320.00 & 16400000.00 \\
Land area (ln) & 178 & 11.71 & 2.24 & 5.77 & 16.61 \\
Latitude & 178 & 0.29 & 0.19 & 0.00 & 0.72 \\
\hline
\end{tabular}


Table B.3. Correlation Table

\begin{tabular}{|c|c|c|c|c|c|c|c|c|c|c|c|c|c|}
\hline & $\begin{array}{l}\text { BOD/ } \\
\text { cap. }\end{array}$ & $\begin{array}{l}\text { BOD/ } \\
\text { wat. res. }\end{array}$ & $\begin{array}{l}\text { W.wat. } \\
\text { tr. }\end{array}$ & QoG & $\begin{array}{l}\text { Dem., } \\
\text { V-dem }\end{array}$ & $\begin{array}{l}\mathrm{FH} / \\
\text { Pol.IV }\end{array}$ & $\begin{array}{l}\text { Corr, } \\
\text { V-dem }\end{array}$ & $\begin{array}{l}\text { GDP/ } \\
\text { capita }\end{array}$ & $\begin{array}{l}\text { Pop. } \\
\text { dens. }\end{array}$ & $\begin{array}{l}\text { Urban } \\
\text { Pop. }\end{array}$ & Area & Lat. & $\begin{array}{l}\text { Wat. } \\
\text { res. }\end{array}$ \\
\hline BOD/capita $(\ln )$ & 1.00 & & & & & & & & & & & & \\
\hline $\mathrm{BOD} /$ water resources $(\ln )$ & 0.29 & 1.00 & & & & & & & & & & & \\
\hline Wastewater treatment & 0.62 & 0.27 & 1.00 & & & & & & & & & & \\
\hline QoG, rescaled & 0.66 & 0.07 & 0.75 & 1.00 & & & & & & & & & \\
\hline Democracy, V-dem, rescaled & 0.47 & -0.20 & 0.53 & 0.61 & 1.00 & & & & & & & & \\
\hline Freedom House/Polity IV & 0.46 & -0.20 & 0.42 & 0.54 & 0.96 & 1.00 & & & & & & & \\
\hline Corruption, V-dem, rescaled & -0.61 & -0.07 & -0.72 & -0.88 & -0.74 & -0.68 & 1.00 & & & & & & \\
\hline GDP/capita (ln) & 0.69 & 0.22 & 0.74 & 0.76 & 0.58 & 0.53 & -0.79 & 1.00 & & & & & \\
\hline Population density $(\ln )$ & 0.22 & 0.46 & 0.21 & 0.04 & -0.02 & -0.06 & -0.01 & 0.13 & 1.00 & & & & \\
\hline Urban Population & 0.53 & 0.18 & 0.68 & 0.63 & 0.44 & 0.41 & -0.65 & 0.76 & -0.03 & 1.00 & & & \\
\hline Land area $(\ln )$ & -0.24 & -0.41 & -0.20 & -0.22 & -0.12 & -0.15 & 0.15 & -0.32 & -0.41 & -0.19 & 1.00 & & \\
\hline Latitude & 0.60 & 0.22 & 0.73 & 0.69 & 0.54 & 0.50 & -0.64 & 0.64 & -0.01 & 0.53 & -0.15 & 1.00 & \\
\hline $\begin{array}{l}\text { Internal renewable } \\
\text { water resources }\end{array}$ & 0.05 & -0.71 & -0.03 & 0.03 & 0.21 & 0.17 & -0.05 & -0.09 & -0.04 & -0.11 & 0.69 & -0.08 & 1.00 \\
\hline
\end{tabular}




\section{Appendix C. Coutries used in the analysis in Table 2}

\begin{tabular}{|c|c|c|c|c|c|}
\hline 1 & Albania & 44 & Norway & 87 & Australia \\
\hline 2 & Argentina & 45 & Pakistan (1971-) & 88 & Armenia \\
\hline 3 & Austria & 46 & Panama & 89 & Brazil \\
\hline 4 & Bangladesh & 47 & Paraguay & 90 & Myanmar \\
\hline 5 & Belgium & 48 & Philippines & 91 & Belarus \\
\hline 6 & Bolivia & 49 & Poland & 92 & Cameroon \\
\hline 7 & Botswana & 50 & Portugal & 93 & Congo \\
\hline 8 & Bulgaria & 51 & Qatar & 94 & Congo, Democratic Republic \\
\hline 9 & Canada & 52 & Romania & 95 & Costa Rica \\
\hline 10 & Sri Lanka & 53 & Saudi Arabia & 96 & Cuba \\
\hline 11 & Chile & 54 & Senegal & 97 & El Salvador \\
\hline 12 & China & 55 & Vietnam & 98 & Gabon \\
\hline 13 & Colombia & 56 & South Africa & 99 & Guatemala \\
\hline 14 & Cyprus (1975-)* & 57 & Zimbabwe & 100 & Guinea \\
\hline 15 & Denmark & 58 & Spain & 101 & Guyana \\
\hline 16 & Dominican Republic & 59 & Sweden & 102 & Honduras \\
\hline 17 & Ecuador & 60 & Syria & 103 & Iceland \\
\hline 18 & Finland & 61 & Thailand & 104 & India \\
\hline 19 & France (1963-) & 62 & Trinidad and Tobago & 105 & Cote d'Ivoire \\
\hline 20 & Gambia & 63 & Turkey & 106 & Jamaica \\
\hline 21 & Germany & 64 & Uganda & 107 & Kenya \\
\hline 22 & Ghana & 65 & Egypt & 108 & Liberia \\
\hline 23 & Greece & 66 & United Kingdom & 109 & Libya \\
\hline 24 & Haiti & 67 & Tanzania & 110 & Mali \\
\hline 25 & Hungary & 68 & United States & 111 & Mozambique \\
\hline 26 & Indonesia & 69 & Yemen & 112 & Namibia \\
\hline 27 & Iran & 70 & Azerbaijan** & 113 & Nicaragua \\
\hline 28 & Iraq & 71 & Croatia & 114 & Niger \\
\hline 29 & Ireland & 72 & Czech Republic & 115 & Nigeria \\
\hline 30 & Israel & 73 & Ethiopia (1993-) & 116 & Papua New Guinea \\
\hline 31 & Italy & 74 & Ethiopia $(-1992)$ & 117 & Peru \\
\hline 32 & Japan & 75 & Estonia & 118 & Guinea-Bissau \\
\hline 33 & Jordan & 76 & Kazakhstan & 119 & Serbia \\
\hline 34 & Korea, South & 77 & Latvia & 120 & Sierra Leone \\
\hline 35 & Lebanon & 78 & Lithuania & 121 & Somalia \\
\hline 36 & Madagascar & 79 & Moldova & 122 & Suriname \\
\hline 37 & Malawi & 80 & Russia & 123 & Switzerland \\
\hline 38 & Malaysia (1966-) & 81 & Slovakia & 124 & Togo \\
\hline 39 & Mexico & 82 & Slovenia & 125 & Tunisia \\
\hline 40 & Mongolia & 83 & Sudan $(-2011)$ & 126 & Burkina Faso \\
\hline 41 & Morocco & 84 & Ukraine & 127 & Uruguay \\
\hline 42 & Netherlands & 85 & Algeria*** & 128 & Venezuela \\
\hline 43 & New Zealand & 86 & Angola & 129 & Zambia \\
\hline
\end{tabular}

Countries 1-69 are present in all models

* for the methodology on the divisions of country-years, see Teorell et al. (2016)

** Countries 70-84 are not included in models 3-6 due to data availability

** Countries 85-129 are only included in models 7-8 due to data availability 


\section{Appendix D. Robustness checks}

\section{Table D.1. Democracy (Freedom House/Polity IV), quality of government and water quality}

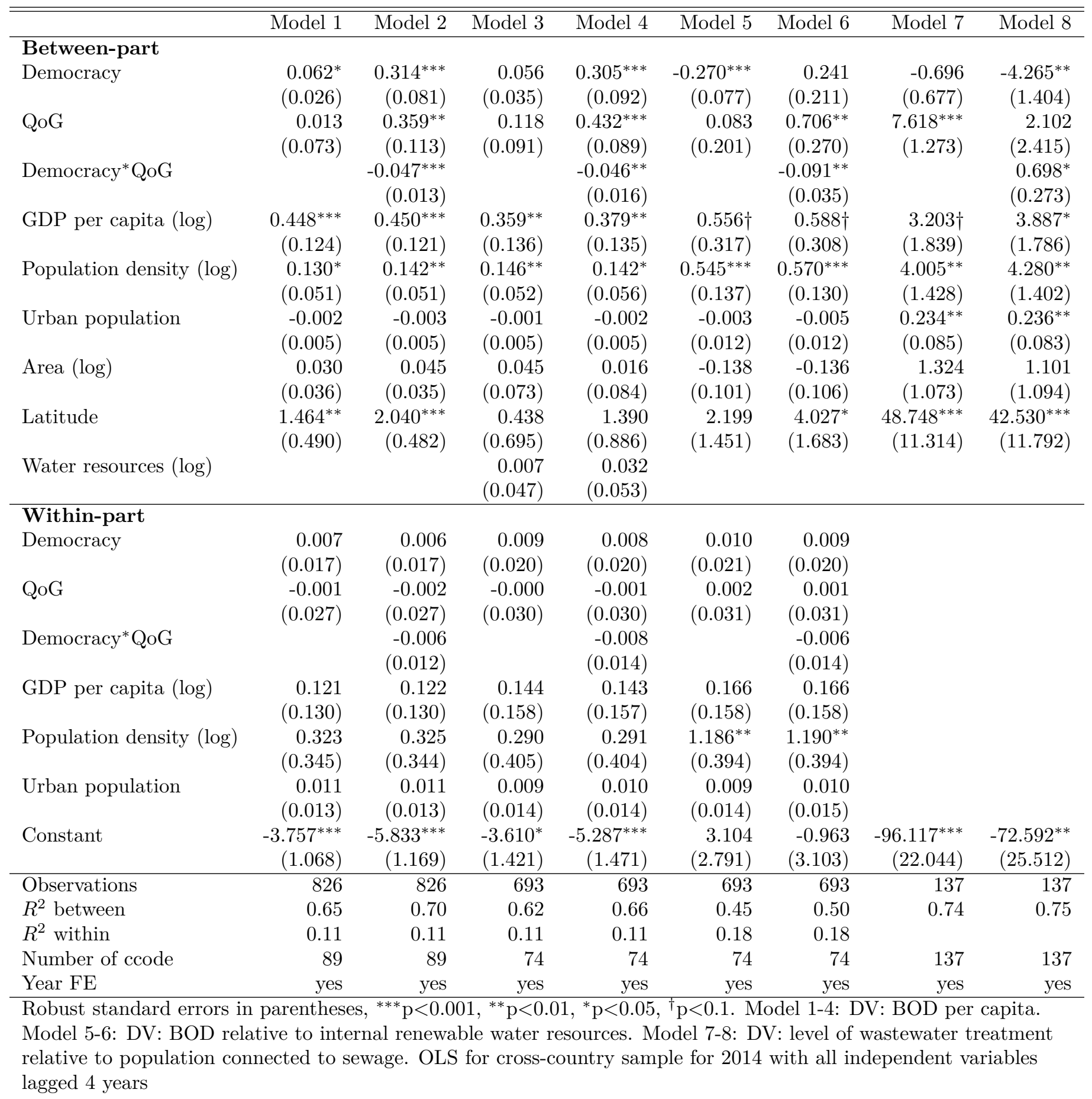



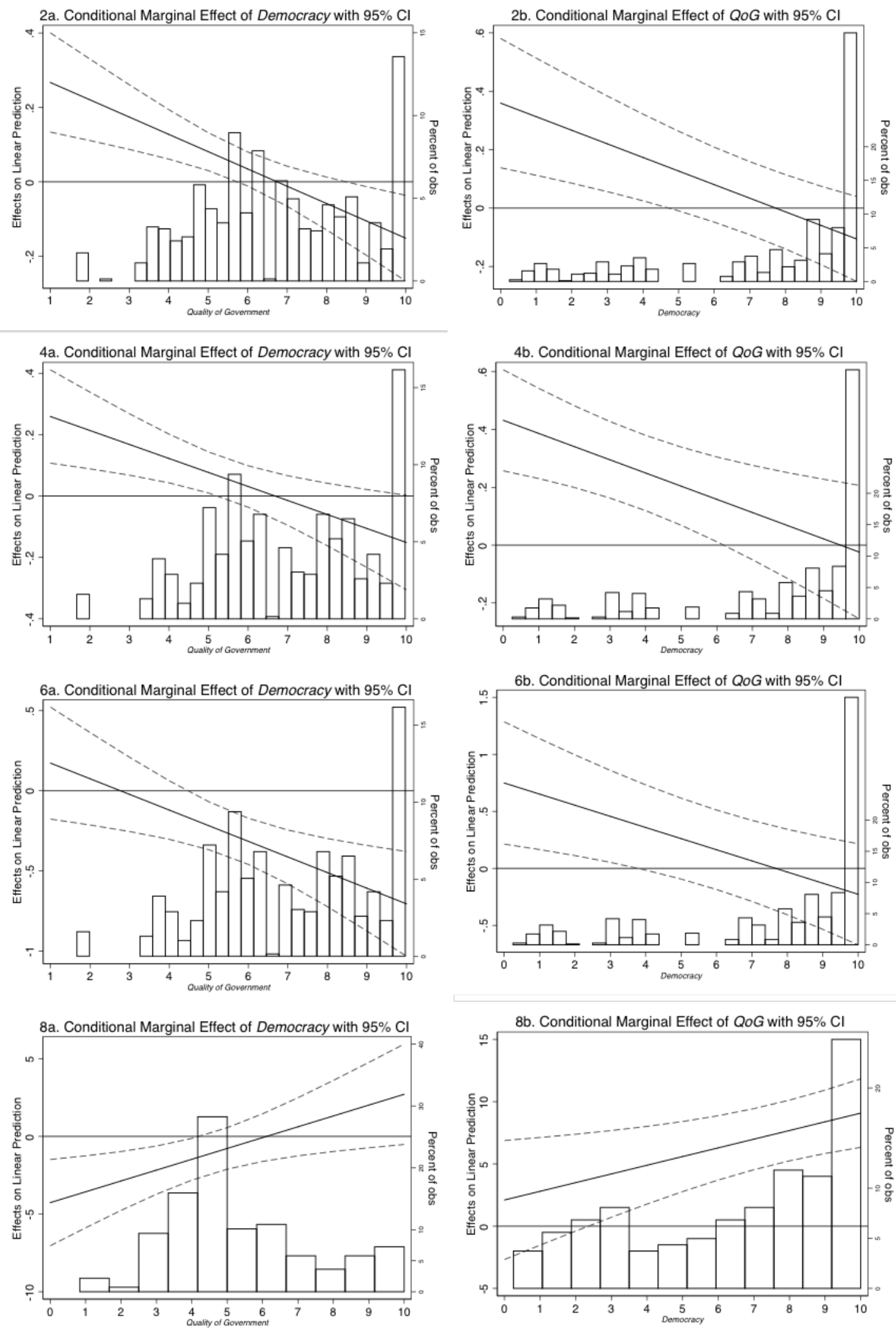

Figure D.1. Conditional marginal effects of democracy and quality of government on water quality 